\title{
Financial Deepening Implications for Macro-economic Volatility and Economic Growth in Nigeria, A Multivariate Approach
}

\author{
Anuli Regina Ogbuagu", Dennis Brown Ewubare ${ }^{2}$ \\ ${ }^{1}$ Department of Economics and Developmental Studies, Federal University, Ndufu -Alike Ikwo, Nigeria \\ ${ }^{2}$ Department of Agriculture and Applied Economics/Ext, Rivers State University of Science and Technology, Port Harcourt, Nigeria
}

Email address:

anulireg@gmail.com (A. R. Ogbuagu), dennisewubare@yahoo.com (D. B. Ewubare)

\section{To cite this article:}

Anuli Regina Ogbuagu, Dennis Brown Ewubare. Financial Deepening Implications for Macro-economic Volatility and Economic Growth in Nigeria, A Multivariate Approach. International Journal of Economics, Finance and Management Sciences. Vol. 5, No. 1, 2017, pp. 66-80. doi: $10.11648 /$ j.ijefm.20170501.16

Received: November 15, 2016; Accepted: December 1, 2016; Published: January 12, 2017

\begin{abstract}
This paper investigates the relationship between financial depth, macroeconomic volatility, and economic growth in Nigeria using a general model of error correction and causality model with time series sourced from Central Bank of Nigeria Bulletin 2012. The result shows a long-run impact of financial deepening on exchange rate volatility and economic growth while the error correction term indicates that there is no long-run impact of financial depth on growth volatility. On one hand, there is no short run impact of financial depth on exchange rate and growth volatility though most of the financial deepening variables show signs of dampening the volatility of exchange rate and growth. On the other hand, the error correction result suggests that there is a long-run and short-run impact of financial deepening on economic growth. The causality result showed no causality between financial deepening variable, economic growth, and growth volatility but a unidirectional causality between exchange rate volatility, stock traded, stock market capitalization, and broad money. We therefore, suggest that government and policy makers to embrace policies that will deepen financial services in Nigeria.
\end{abstract}

Keywords: Financial Deepening, Macroeconomic Volatility, Economic Growth, Exchange Rate, Error Correction, Causality

\section{Introduction}

Economic growth and development has been viewed to be essentially linked to high levels of monetization of an economy and invariably, financial development. This is particularly true in less developed economies where it is believed that the provision of adequate financial resources is a prerequisite for economic transformation. The velocity of this transformation will be affected by the degree of financial service industries that is prevalent in the economy. Hence, financial institutions contribute to the real productivity of the economy and to the overall standard of living giving their capacity to satisfy the needs and preferences of surplus and deficit units of the economy [1]. Financial development is necessary in advancing the economic growth process of a country, and also in reducing the volatility of price and growth process. Also [2] noted that financial system development can alleviate the liquidity limitation on firms and assist long-term investment, which eventually reduces the volatility of price, investment and growth; in addition it stimulates the acquisition and dissemination of information, ease risk diversification and management and assists resource mobilization. With all these advantages noted, financial sector in Nigeria, in recent time have become wider over the two decades, however not inclusive.

In the wake of this, a number of factors have been adduced to be responsible for this; one is structural characteristics of the Nigerian environs, ineffective policy factor problems, and exogenously determined factors (like; lack of technical advancement, socio-political and religious conditions), low productivity, a high degree of illiteracy level and low population concentration in the urban areas and more informal sector arrangement. These structural and environmental factors are very important because they form 
the bases for financial deepening. All these factors combined together, prevent the financial sector's growth in less developed countries and makes it difficult for large population to assess and benefit from formal financial services. According to [3], demand and supply factors limits financial deepening in developing countries in the areas of low mobilization of deposits, lack of collateral, high level financial illiteracy, high service charge, documentation requirements and lack of basic infrastructure limits financial intermediation.

Both theoretical and empirical literatures have laid emphasis on the nexus between financial deepening and economic growth. [4] identifies two possible causal relationships between financial development and economic growth. They are "demands-following hypothesis" and "supply-leading hypothesis". The demand-following hypothesis posits a unidirectional causation from economic growth to financial development, see the demand for financial services as dependent on the growth of real output while the supply-leading hypothesis holds a reverse relationship. It is also important to note that one of the major benefits of financial deepening is its ability to mitigate macroeconomic volatility. Many theoretical literatures have outlined various channels through which financial development can affect macroeconomic volatility. And in the light of this, [5] expand a theoretical model that merge financial market imperfections and unequal access to investment opportunities to show that economies with poor financial systems tend to be more volatile as the demand for and supply of credit are more cyclical in such countries. The preposition that financial deepening promotes economic growth has been supported and advanced by a good number of a well-known economists like [6, 7, 8, 9, 10]. Also, [11] found a supply-leading hypothesis in Tanzania and Demand following hypothesis in Kenya and SouthAfrica, [12] found a bi-causality relationship in Japan. On one hand many authors have equally discovered a direct impact of financial sector development on economic growth. [See 13, 14, 15]. On the other hand, $[16,17,18]$ ascertain no positive and significant relationship between financial development on economic growth.

In Nigeria, existing literature have tried to establish the relationship between financial development and economic growth. For example, $[19,20,21]$ examine the relationship between financial sector development and economic growth in Nigeria; producing divergent results. The existing literature is grossly lacking in results that will produce measures that necessary to mitigate the adverse effects of financial deepening volatility on macroeconomic variables. Therefore the study intends to fill the research gap by exploring the impact of financial development on growth and macroeconomic volatility in Nigeria. In specific terms, we examine the short-run and long-run effects of financial deepening on growth and volatility, and to analyze the direction of causality between financial development, macroeconomic volatility and economic growth in Nigeria using Granger Causality test. When established, it will help policy makers to embrace appropriate policies that will help reduce the adverse effects of volatility relative to financial deepening in the macro-economic environment.

\section{Theoretical and Empirical Literature}

\subsection{The Concept of Financial Deepening}

According to [21], defined financial development as a combination of depth (size, and liquidity of market), ability of individual to access financial services and the efficiency of the institutions to provide financial services at low cost and with sustainable revenue, and the level of activity of the capital market.

\subsection{Theoretical Relationship Between Financial Development, Economic Growth and Macroeconomic Volatility}

The theoretical literature has two sides of the relationship but the question is as in the chart below;

\section{Does financial sector development spur economic growth}

or

\section{Does economic growth leads to financial Deepening}

Figure 1. Two Sides of the Theoretical Literature.

The interrelationship between economic growth and financial sector development is abounding in literature both for developed and developing countries. Some previous literature has established a demand following hypothesis (that is unidirectional relationship from economic growth to increased demand of financial services leading to deepened financial sector) while others supported that financial sector development is a necessary link to achieve economic growth.
Others have equally emphasized on the bidirectional causality between finance and economic growth.

Previous theoretical literature have established that there is a strong link between financial development and economic growth, but the emergence of financial institutions and markets does not in itself imply a direct positive impact on economic growth. Many scholars have equally established empirically that there is positive correlation between 
financial development and economic growth because financial development provides enabling environment for an inclusive growth through channels. Theoretical literature affirmed that there are two way relationship that exist between financial deepening and growth; one is through supply leading hypothesis (financial development spurs growth) or demand-following (growth generates demand for financial products which in turn provides a channel of well deepened finance). According to [22] indicates how financial markets can alleviate the market frictions and the inability of the market to diversify risks that led to poor success of the financial market in the developing countries. But economic growth and macroeconomic stability depends on the extent of financial sector development and on the other hand financial sector development depends on the many macroeconomic factors and a lot of literatures have tried to outline this interdependent link. In the earliest study done by $[6,7,24]$, an enhanced investment and efficient financial structure and stable macroeconomic environment can help economies to achieve and sustain growth.

Equally, studies affirmed that a deepened financial sector promotes financial stability to the extent that deep and liquid financial systems with diverse investments helps to dampens macroeconomic shocks and improves resource allocation through an improved macroeconomic policy effectiveness. A well managed financial deepening enhances resilience and capacity to cope with macroeconomic shocks, boosts economic productivity by mobilizing savings from surplus economic unit to deficit unit, and facilitates diversification and proper risks management through improved information sharing. [25] identified the channels through which financial development can enhance growth to include; provision of information, allocation of capacity to productive uses, monitoring of financial investment, easing exchange of goods and services, mobilizing and pooling savings for investments.

Current states of Nigerian Financial development, financial sector development have received much attentions in recent time and have grown and become more inclusive since year 2000 but still there are challenges for a deepened financial sector and they include; the structural characteristics of countries, policy factors (most time ineffective policy can impede financial depth), lack of technological skills, and socio political and religious condition. Also a confluence of demand and supply factor can constrain financial depth (low mobilization of deposit, financial illiteracy, high cost of funds and documentation requirement can limit financial intermediation, persistent macroeconomic instability, weak collateral regimes. These factors can determine the extent Nigeria can go in achieving a deepened financial depth.

But mitigation of macroeconomic volatility is still one of the foremost advantages of a well deepened financial sector and in support of the earliest studies $[6,7,5]$ using a theoretical model of financial market imperfection and unequal access to investment proved that economies with inefficient financial structure are more inclined to macroeconomic volatility. While [23 and 18] in a separate studies, showed that deeper and efficient financial system facilitates diversification, reduces financial and investment risks, dampens the fluctuation and fiscal shocks. Amplify monetary shocks and invariably lead to growth. All the above listed are the theoretical benefits accruing from a well deepened financial environment. But the structural characteristics of developing countries more times made it impossible and impede them from reaping the benefits that evolve from financial depth. First the developing countries are limited in export/import diversification and this weakens their strength in world trading and leads to fluctuation in demand and supply links. According to [26], indicated in his study that the political structure of societies is important because it is critical for development of financial system.

However, having ascertained the theoretical advantages of financial depth, some studies do not find positive relationship between financial deepening, growth and volatility, for example; [16] support a negative correlation between financial depth and growth, consumption, and investment volatility. And $[17,18]$ do not find a robust relation between financial intermediary development and growth volatility.

\subsection{Current State of the Financial Sector Development in Nigeria}

Nigeria has a huge financial system and one of the largest in African continent comprising of banks and non-bank institutions. And these institutions include 89 commercial and merchant bank, 1000 community banks and people's bank, 7 development bank, 5 discount houses and over 1000 bureaux de change (Nigerian Financial Sector Review 2000). With these seemingly robust financial system, Nigeria suppose to be on top of her growth agenda but there is disconnect between the financial sector and the real sector development. And this state of affair have been attributed to many factors which includes; weak governance, undercapitalization of the financial institutions, nontransparency of ownership structure of the financial institutions, lack of proper financial report, and corruption in the system [27].

These entire factors combined together contributed to the weakness and failure of financial sector in Nigeria, that lead to financial institution crisis of the late 1990s and early 2000. Therefore the banking sectors were consolidated from 89banks in 2005 to 20banks in 2012 along side recapitalization [27]. But despite significant progress made in the banking sector reforms; the regulatory and supervisory framework have weaknesses and operate in a harsh economic environment hence a disconnect from achieving her utmost goal.

Below figure 2; shows graphical representation of current state of selected financial depth indicators; 


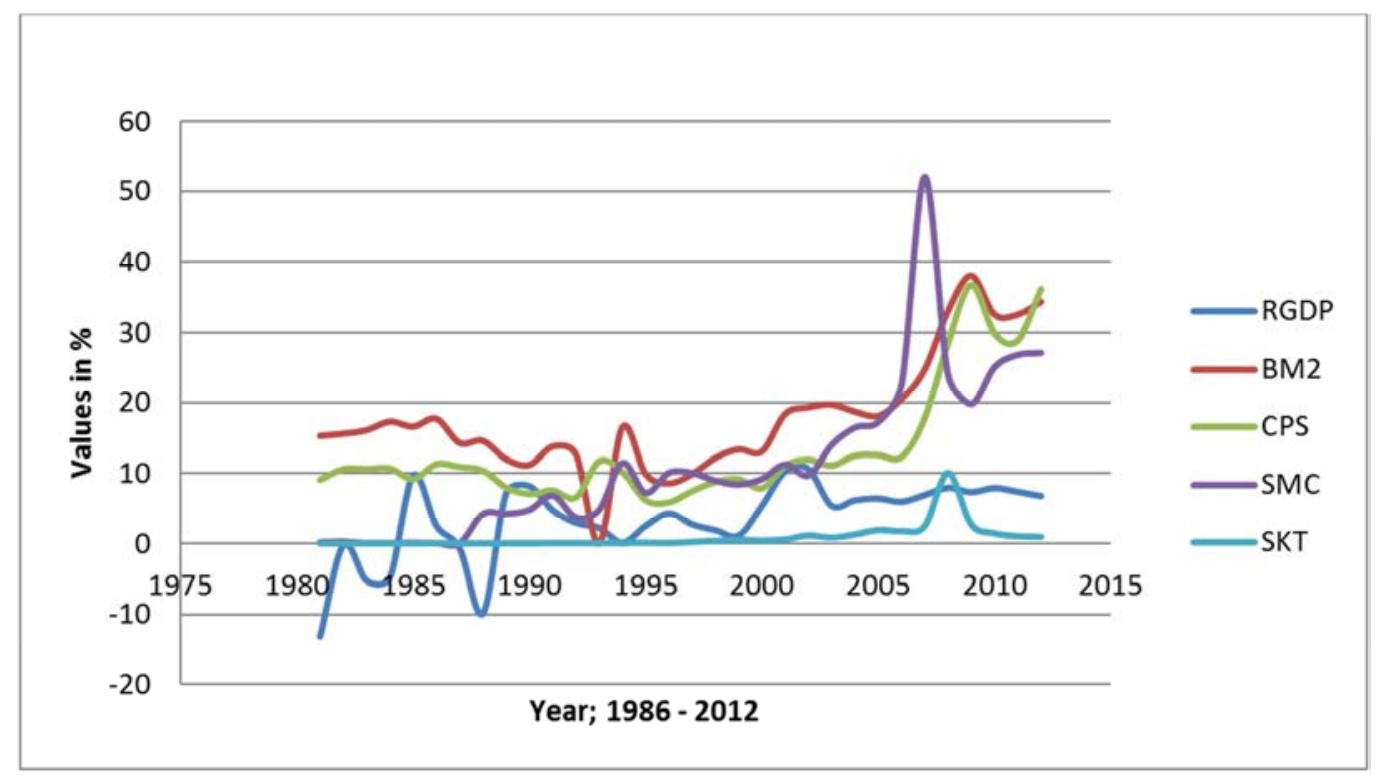

Source; Data Collected from CBN Bulletin 2014

Figure 2. Shows the relationship between real GPD, and the indicators of fiancial sector depth (Broad money (BM2), Credit to Private sector (CPS) stock market capitalization (SMC) and stock traded (SKT).

The financial deepening variables used here are (broad money (M2) and private sector credit (CPS) as a ratio of GDP) measuring financial institution depth while stock market capitalization and stock traded ration to GDP measures the depth of financial market. And the above chart indicates the trends over period from 1988 to 2012 alongside the growth rate proxied by real gross domestic product in percentage.

Challenges of Nigerian Financial Sector

a) Persistent macroeconomic and political instability of the Nigerian economy is a natural odds that does not contribute meaningfully to the development of financial sector.

b) Policy factors; inconsistence of policy implementation by successive government is another factor that impede growth and inclusive financial sector development

c) Lack of expanded access to financial service due to urban/rural population density.

d) Structural characteristics of Nigeria; lack of technical knowhow, sociopolitical condition, religious influences, all these factor prevent deepening of financial sector

e) A convergence of demand and supply factor, for example high cost of financial provision, financial illiteracy, low mobilization of deposits, low productivity. These factor combined together explains the current state of Nigerian financial sector and

\subsection{Empirical Literature}

\subsubsection{Empirical Evidence on the Impact of Financial Deepening on Economic Growth}

Many strand of empirical literature have investigation the relationship between financial development and economic growth both in developed and developing countries using different empirical methods and different proxies as measurement for financial development. The empirical literatures are divided into two; those that supports the supply leading hypothesis abounds in the literature and some of them are; For instance, [12] investigate the threshold cointegration effect of financial deepening on economic growth in Taiwan over the period from 1981 to 2010. The results show that a threshold cointegration effect exists in relationship between financial deepening and economic growth. In short-run, economic growth has a significant and positive effect on financial deepening in the high-growth regime. This implies that economic growth can stimulate financial deepening in Taiwan in the high-growth regime. In addition, the impact of financial deepening on economic development has a significant and positive effect in the highand low-growth regimes. [28] using general equilibrium model discovered a positive and significant impact of deregulation and financial development on investment for Latin American, [29] implores autoregressive distributed lag model to examine the link between financial development and economic growth in Saudi Arabia, the result shows a statistically significant long-run relationship and no bidirectional causality in the short run. In Kenya, [30] apply error correction model and found a positive link from financial depth and economic growth. [31] utilized grangercausality test and error correction framework established a long-run positive impact of financial depth on growth in Saudi-Arabia, Turkey, and United Arab Emirate. Likewise in Ghana [32] supports the supply leading hypothesis using cointegration and causality test. In addition, [33, 34, and 35] also in their respective empirical studies for their countries supports the supply leading hypothesis. 
On the other hand, other studies found negative impact of financial development on economic growth and among them are; [36] using cointegration and granger causality found no long-run impact of financial deepening on real GDP in Asian. While [37] employed province-level data to explore the relationship between financial deepening on economic growth in Turkey, they found strong negative relationship.

\subsubsection{Empirical Evidence on the Impact of Financial Development and Macroeconomic Volatility}

[38] explore the impact of international financial integration on macroeconomic volatility using panel data model and the result indicates that financial integration help reduce output growth volatility, improves risk sharing and consumption smoothing beyond threshold. In another research, [39] used a reduced form approach and intense sensitivity analysis to test how international financial remoteness affects macroeconomic volatility; they found that the further a country is to international finance activities, the more volatile output, consumption and growth are. Likewise [40] conducted a research for a sample of emerging markets and low-income countries (LICs) using a benchmark specification and discover that developed economies they experience less volatility in real per capita output, consumption and investment growth.

[41] investigates the role of financial market development on business cycle volatility in Korea using long-run causality index, the result shows that the measures of financial deepening mitigates cyclical fluctuations in the long run. [10] explore the relationship between financial deepening and economic growth in Saudi Arabia using time series data. The study uses the Autoregressive Distributed Lag model of co-integration involving financial depth or size of the financial intermediaries measured by the monetization ratio (M2/GDP). The results show a positive and statistically significant long-run relationship between financial deepening (measured by M2/GDP) and economic growth, (proxied by Gross Domestic Product (GDP) growth per capita). However, there is no evidence of the short-run dynamic bi-directional relationship between the variables. In general, the result supports the supply-leading hypothesis that financial deepening spurs economic growth in the case of Saudi Arabia. While [42], applied pedroni panel cointegration and panel error correction model for 19 developed and 21 developing countries, found that stock market turn over contributes more to stock market returns than stock market liquidity for both developed and developing countries, though the result are much weaker for developing countries.

In Africa, [43] introduced trade liberalization as one of the indicator to check the relationship between financial development, real output and consumption volatility, the result showed a robust and significant effect of financial liberalization on stabilizing and smoothing consumption and output growth and negative impact of financial market indicators on output and consumption volatility. In Nigeria, [44] use a different approach involving Real Gross Domestic Product, Financial Deepening - a ratio of money supply to Gross Domestic Product, liquidity ratio, interest rate and credit to the private sector. On one hand, the study finds that financial sector development does not have a significant improvement in private sector development. On the other hand, the minimum capital base and liquidity ratio lead growth economic growth in Nigeria. Other studies also have found positive relationship between growth and financial development. For example; [45], finds a significant impact of financial intermediation on growth while [13] finds positive link between financial structure and growth. [1], employed Autoregressive distributed lag model (coefficient diagnostic and variance decomposition test) explored the relationship between financial deepening and inflation in Nigeria in an open economy model. The paper suggests that there exists long run significant impact of financial deepening on consumer price index. Finally, [46] affirmed using GARCH $(1,1)$ model that financial deepening reduces volatility in the stock market.

\section{Model Specification/Methodology}

\subsection{Model Specification}

First, we adopt the ex-post facto research framework involving a Multivariate Model (MVA). The methodology has been variously applied in works involving financial deepening and macro-economic instability (e.g) [13]. The choice of the model is based on the use of more than single independent variable in the study. The general form of the model is thus specified in equation (1) below:

$$
Y=\beta_{0}+\beta_{1} X_{1}+\beta_{2} X_{2}+\ldots \beta_{n} X_{n}+\mu
$$

where; $Y=$ dependent variable, $\beta_{0}=$ equation constant, $\beta_{1}$, $\beta_{2}, \ldots, \beta_{\mathrm{n}}=$ coefficients of explanatory variables $X_{1}, X_{2}, \ldots, X_{n}$ = independent or explanatory variables $\mu=$ error term.

Given the above general multiple regression function, proxies for financial deepening are the Financial Institution Depth (Broad Money Ratio (M2/GDP) and Credit to Private Sector Ratio to GDP(CPS/GDP)) and the Financial Market Depth (Stock Market Capitalization Ratio of GDP (SMC/GDP) \& Stock Traded Ratio to GDP (ST/GDP)).

The dependent variables are RGDP (Real Gross Domestic Product in percentage - a proxy for economic growth); EXRV (Exchange Rate Volatility); GDPV (Growth Volatility); and CPI (Price Index - a Control Variable Consumer)

Therefore, our estimated equations are thus;

$$
\begin{gathered}
\operatorname{exrv}_{t}=b_{o t}+b_{1} \operatorname{rgdp}_{t}+b_{2} s k t_{t}+b_{3} s m c_{t}+b_{4} \operatorname{cps}_{t}+b_{5} b m 2_{t}+b_{6} c i_{t}+\mu_{t} \ldots \\
\operatorname{gdpv}_{t}=b_{o t}+b_{1} \operatorname{exrv}_{t}+b_{2} s k t_{t}+b_{3} \text { smc }_{t}+b_{4} \operatorname{cps}_{t}+b_{5} b m 2_{t}+b_{6} c i_{t}+\mu_{t} \ldots
\end{gathered}
$$




$$
\operatorname{rgdp}_{t}=b_{o t}+b_{1} \operatorname{erXv}_{t}+b_{2} s k t_{t}+b_{3} s m c_{t}+b_{4} c_{p s}+b_{5} b m 2_{t}+b_{6} c_{t} i_{t}+\mu_{t} \ldots
$$

\subsection{Variables Definition}

For the purpose of this research we used exchange rate volatility and growth volatility. Volatility is measured as the simple five year standard deviation of the variables.

Measurement of Financial Depth

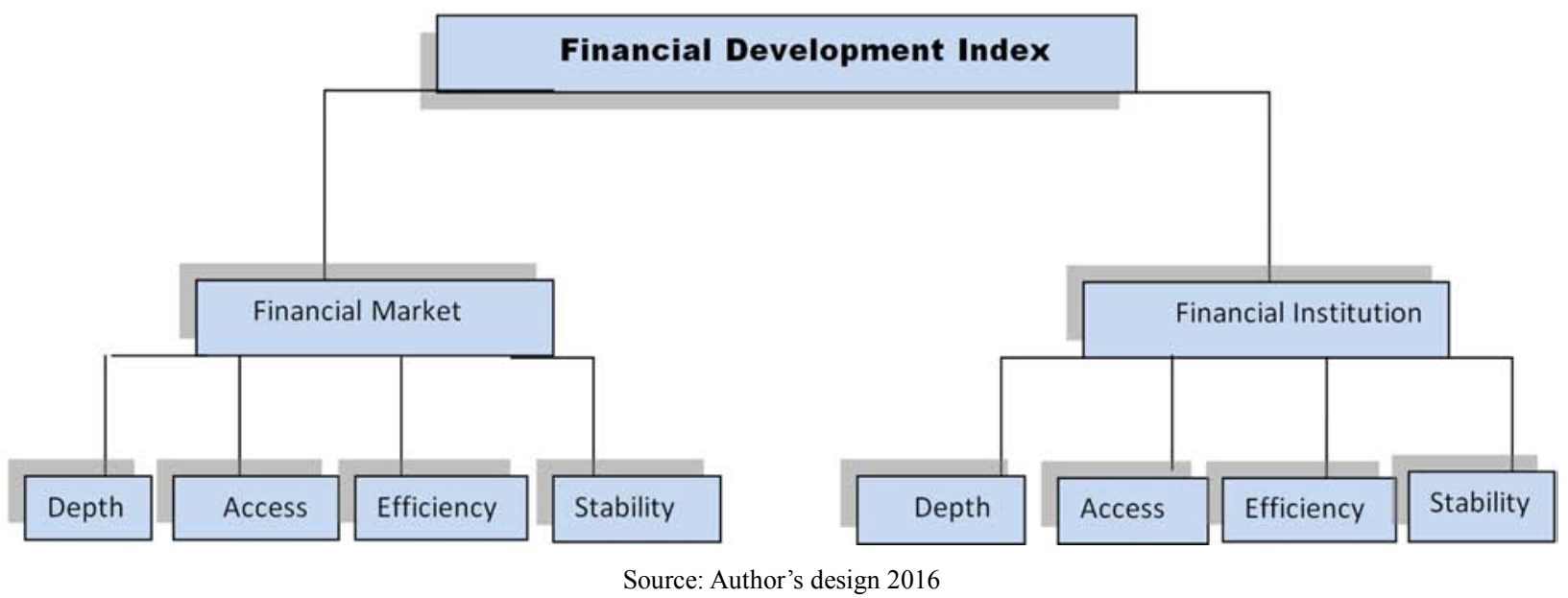

Figure 3. Represent the Summary of Financial development index developed by World Bank Financial Paper (1999).

To measure the depth of financial sector we used a simple conceptual 4x2 framework sourced from the World Bank's Global Financial Development Database. This framework identifies four sets of proxy variables characterizing a well-functioning financial system: financial depth, access, efficiency, and stability. These four dimensions are then measured for the two major components in the financial sector, namely the financial institutions and financial markets [47].

Table 1. Financial Depth Indicators.

\begin{tabular}{lll}
\hline & Financial Institutions & Financial Markets \\
\hline & Private Sector Credit to GDP & Stock Market Capitalization \\
& Financial Institutions' asset to GDP & Outstanding Domestic Private Debt \\
M2 to GDP & Securities to GDP \\
Depth & Private Debt securities to GDP \\
& & Public Debt Securities to GDP \\
& Gross value added of the financial sector to GDP & International Debt Securities to GDP \\
& & Stock Market Capitalization to GDP \\
\end{tabular}

Source: (The World Bank Financial Paper, 1999)

\subsection{Methodology and Time Series Property of Data Used}

\subsubsection{Sources of Data}

Our time series data was sourced from Central Bank of Nigeria's publications (Statistical Bulletin, and annual reports and statement of Accounts 2012).

The methodology applied in this study following the literature is based on time series data sets. The estimation procedure adopted in deriving the estimates of the parameters of economic relationships is the Ordinary Least Squares (OLS).

\subsubsection{Unit-Root Test}

There often exists the problem of non-stationarity in empirical research involving time series data and this renders the traditional tools of econometrics (like OLS) inappropriate. To check this problem we test for stationarity of the variable. We employed The Augmented Dickey-Fuller test (ADF) It is specified as follows (Ogbuagu and Ifionu
2015):

$$
\Delta Y_{t}=\theta_{o}+\theta_{1} Y_{t-1}+\sum_{i=1}^{k} b_{i} \Delta Y_{t-i}+\mu_{t}
$$

Where, $Y_{t}$ is a vector of all variables in the model $\theta_{i}$ and $b_{i}$ are parameters of the model, $\mu_{\mathrm{t}}$ is the white noise at time while $k$ and $\Delta$ remain as defined. This we will achieve, conducting the test by first or second level difference if the series are integrated of order one or order two (i.e. I(1) or $\mathrm{I}(2)$ ). The null hypothesis here is that $Y_{t}$ has a unit root (that is, non-stationary) and the alternative is that there is no unit root (that is, stationary). If the variables turn out to contain unit roots, we will therefore, conclude that they are nonstationary [48]:

\subsubsection{Johansen Co Integration Test}

Johansen co integration (Trace and Maximum Eigenvalue 
statistics) will be used to ascertain the long run associationship of the dependent and independent variables.

(1) To achieve the first objective; we adopt General to Specific Error Correction Model (GSECM)

The basic structure of an ECM

$$
\Delta \mathrm{Yt}=\mathrm{a}+\beta \Delta \mathrm{Xt}-1-\beta \mathrm{ECt}-1+\mathrm{et}
$$

Where EC is the error correction component of the model and measures the speed at which prior deviations from equilibrium are corrected. Error correction models can be used to estimate the following quantities of interest for all $\mathrm{X}$ variables.

(2) To achieve objective two, Pairwise Granger Causality

Tests was performed;

We test for the absence of Granger Causality by estimating the following model;

$$
\begin{gathered}
Y_{t}=a_{0}+a_{1} Y_{t-1}+\ldots+a_{p} Y_{t-p}+b_{1} X_{t-I}+\ldots+b_{p} X_{t-p}+Y_{t} \\
X_{t}=C_{o}+C_{1} X_{t-1}+\ldots+C_{p} X_{t-p}+d_{1} Y_{t-I}+\ldots+d_{p} Y_{t-p}+V_{t}
\end{gathered}
$$

Testing $\mathrm{H}_{\mathrm{o}} \mathrm{b}_{1}=\mathrm{b}_{2}=\ldots \mathrm{b}_{\mathrm{p}}=0$

Against $\mathrm{H}_{1}$ : Not $\mathrm{H}_{0}$

Is a test that $\mathrm{X}_{\mathrm{t}}$ does not granger cause $\mathrm{Y}_{\mathrm{t}}$.
Similarly, testing $\mathrm{H}_{\mathrm{o}}: \mathrm{d}_{1}=\mathrm{d}_{2}=\ldots \mathrm{d}_{\mathrm{p}}=0$ against

Against $\mathrm{H}_{1}$ : Not $\mathrm{H}_{0}$ is a test that $\mathrm{Y}_{\mathrm{t} \text {. }}$ does not granger cause $X_{t}$

In each case a rejection of the null hypothesis implies that there is Granger Causality between the variables.

In testing for granger causality, two variables are usually analyzed together, while testing for their interaction. All the possible results of the analyses are four.

a) Unidirectional granger causality from variable $Y_{t}$ to variable $X_{t}$

b) Unidirectional granger causality from variable $X_{t}$ to variable $\mathrm{Y}_{\mathrm{t}}$

c) $\mathrm{Bi}$ - directional causality and

d) No causality.

\section{Results}

\subsection{Unit Root Test}

Our result indicates that stock traded (Skt) and real gross domestic product (rgdp) is significant at level (0) while all

\begin{tabular}{|c|c|c|c|c|c|c|}
\hline & Level & & & $1^{\text {st }}$ Differe & & \\
\hline Variable & Intercept & Trend & no Trend & Intercept & Trend & no Trend \\
\hline Exrv & 0.8820 & 0.4080 & 0.8891 & 0.0000 & 0.0003 & 0.0000 \\
\hline Rgdp & 0.0011 & 0.0063 & 0.0035 & 0.0000 & 0.0010 & 0.0000 \\
\hline Skt & 0.0209 & 0.0063 & 0.0048 & 0.0000 & 0.0000 & 0.0000 \\
\hline Smc & 0.3419 & 0.0098 & 0.3401 & 0.0000 & 0.0010 & 0.0000 \\
\hline Gdpv & 0.0947 & 0.5038 & 0.0032 & 0.0001 & 0.0001 & 0.0000 \\
\hline Cps & 0.9991 & 0.9960 & 0.9922 & 0.0004 & 0.0001 & 0.0000 \\
\hline Cpi & 1.0000 & 0.9984 & 0.9822 & 0.0098 & 0.0048 & 0.0005 \\
\hline
\end{tabular}
are significant at first difference.

Table 2. Augmented Dickey- Fuller Unit Root Test Result (probability values).

Source: - Author's computation (2016)

\subsection{Johansson Cointegration Test Result}

Both Trace and Max-eigenvalue indicates four (4) cointegrating equation(s) at 0.05 levels for the three models. And this shows also that our models have long-run relationship.

\subsection{General to Specific Model of ECM}

Having reached conclusion on the inherent long-run relationship using Johansen co integration test, we proceeded to evaluate our models using general to specific model of ECM to check the short \& long-run impact of financial deepening on macroeconomic volatility and economic growth. The models were estimated and the terms with insignificant coefficients were progressively eliminated from the equation inorder to achieve a parsimonious ECM and the results are thus presented below;

Table 3. Error Correction Result for Model 1.

Dependent Variable: Exrv

\begin{tabular}{llll}
\hline Variable & Coefficient & Std. Error & t-Statistic \\
\hline C & 5.871959 & 8.877876 & 0.661415 \\
D(SKT $(-2))$ & 18.99341 & 14.56656 & 1.303906 \\
D(SKT(-3)) & 8.603156 & 5.466588 & 1.573771 \\
D(SMC(-3)) & -3.073568 & 3.283933 & -0.935941 \\
D(CPS(-2)) & -4.645098 & 3.214775 & -1.444922 \\
D(CPI(-1)) & 1.082445 & 1.234189 & 0.877049 \\
U(-1) & -0.452218 & 0.214043 & -2.112742 \\
R-squared & 0.212936 & 0.1305 & \\
Adjusted R-squared & -0.011940 & & 0.1632 \\
Log likelihood & -131.1729 & & 0.0468 \\
Durbin-Watson stat & 2.025133 & F-statistic & \\
\hline
\end{tabular}

Source: - Author's computation (2016) 
From the above table 3 , the error correction terms $(\mathrm{u}(-1))$ is rightly signed and significant with the coefficient of (0.452218) meaning that the speed of adjustment to equilibrium is poor though there is a strong long run relationship existing between financial deepening and exchange rate volatility.

In the short run, there is no significant impact of financial deepening variables in all the lags on volatility but stock market capitalization $(\mathrm{smc})$ in lag 3 , credit to private sector (cps) in lag 2 have a reduction impact on exchange rate volatility.

R-square $(0.212936)$ meaning that the explanatory variable can only explain variation 21 percentvariation in exchange rate volatility. Breusch-Godfrey Serial Correlation LM Test indicates no autocorrelation, the Arch -LM shows no heteroscadascity and the normality test depicts that the model is not normally distributed.

Table 4. Parsimonious ECM Result for Model 2.

Dependent Variable: GDPV

\begin{tabular}{lllll}
\hline Variable & Coefficient & Std. Error & t-Statistic & Prob. \\
\hline C & -1.779322 & 0.751269 & -2.368423 & 0.0286 \\
D(EXRV(-1)) & 0.018182 & 0.020368 & 0.892714 & 0.3832 \\
D(SKT(-1)) & -0.281107 & 0.305650 & -0.919703 & 0.3693 \\
D(CPS(-1)) & 0.299787 & 0.328964 & 0.911305 & 0.3736 \\
D(CPS(-3)) & -0.653300 & 0.410213 & -1.592587 & 0.1278 \\
D(BM2(-1)) & -0.410274 & 0.356118 & -1.152074 & 0.2636 \\
D(BM2(-3)) & 0.511035 & 0.370071 & 1.380912 & 0.1833 \\
D(CPI(-3)) & 0.245263 & 0.121807 & 2.013532 & 0.0584 \\
U(-1) & -0.019389 & 0.021659 & -0.895227 & 0.3819 \\
R-squared & 0.242101 & & & \\
Adjusted R-squared & -0.077014 & & & \\
Log likelihood & -60.28433 & F-statistic & & 0.758663 \\
Durbin-Watson stat & 1.325730 & Prob (F-statistic) & 0.641895 \\
\hline
\end{tabular}

Source: - Author's computation (2016)

Table 5. Parsimonious EC Result for Model 3.

Dependent Variable: $R G D P$

\begin{tabular}{lllll}
\hline Variable & Coefficient & Std. Error & t-Statistic & Prob. \\
\hline C & 4.399410 & 1.270167 & 3.463646 & 0.0032 \\
D(EXRV(-1)) & -0.134912 & 0.035413 & -3.809632 & 0.0015 \\
D(EXRV(-3)) & -0.091580 & 0.028811 & -3.178659 & 0.0058 \\
D(SKT(-1)) & 2.164419 & 0.647155 & 3.344515 & 0.0041 \\
D(SKT(-2)) & 2.685199 & 0.775681 & 3.461731 & 0.0032 \\
D(SKT(-3)) & 1.111468 & 0.558041 & 1.991731 & 0.0538 \\
D(CPS(-1)) & -2.725916 & 0.611765 & -4.455826 & 0.0004 \\
D(CPS(-3)) & 2.200032 & 0.413663 & 5.318420 & 0.0001 \\
D(BM2(-1)) & 2.615627 & 0.562592 & 4.649241 & 0.0003 \\
D(BM2(-2)) & -1.416184 & 0.365820 & -3.871262 & 0.0014 \\
D(CPI(-2)) & -0.535865 & 0.167112 & -3.206628 & 0.0055 \\
U(-1) & -0.151106 & 0.039831 & 3.793700 & 0.0016 \\
R-squared & 0.714608 & & & \\
Adjusted R-squared & 0.518400 & & & \\
Log likelihood & -68.25088 & F-statistic & & 3.642106 \\
Durbin-Watson stat & 1.905952 & Prob (F-statistic) & 0.009674 \\
\hline
\end{tabular}

Source: Author's Computation (2016).
From the above table 4 , the error correction terms $(\mathrm{u}(-1))$ is not rightly signed and insignificant with the coefficient of (-0.019389) meaning that the speed of adjustment to equilibrium is very poor therefore there is no long run relationship existing between financial deepening and growth volatility.

In the short run there is no impact of financial deepening on growth volatility though most of the financial deepening variable have a reduction impact on volatility but not significant.

R-square $(0.242101)$ meaning that the explanatory variable can only explain variation 24 percent variation in exchange rate volatility. Breusch-Godfrey Serial Correlation LM Test indicates no autocorrelation, the Arch -LM shows no heteroscadascity and the normality test depicts that the model is not normally distributed.

Achievement of economic growth is the prime objective of any economic policy agenda. The error correction result indicates a strong long run impact of financial deepening on volatility and growth though the speed of adjustment to equilibrium is 15 percent; very poor.

The short run result designate that the stock traded (skt) in lag $(1,2,3)$, credit to private sector (cps) in lag (1\&3), the broad money (BM2) in lag (1\&2) all have a significant impact on economic growth. But cps(-1) and BM2 (-2) was used to reduce the level of growth level.

Obviously, stock market capitalization has no significant impact on growth. And finally, our control variables; exchange rate volatility (exrv) in lag $(1 \& 3)$ and consumer price index (cpi) in lag (2) have negative and significant impact on the level of growth for the period under review.

The model has a good fit of R-squared 71per cent, durbinWatson stat indicates no autocorrelation and the overall model is significant with the Fprob $=0.009674$. Breusch-Godfrey Serial Correlation LM Test indicates no autocorrelation, the Arch - LM shows no heteroscadascity and the normality test depicts that the model is normally distributed.

Table 6. Pairwise Granger Causality Result.

\begin{tabular}{lll}
\hline Null Hypothesis: & F-Statistic & Probability \\
\hline EXRV does not Granger Cause RGDP & 3.08253 & 0.16359 \\
RGDP does not Granger Cause EXRV & 0.57216 & 0.57152 \\
GDPV does not Granger Cause RGDP & 1.35724 & 0.27569 \\
RGDP does not Granger Cause GDPV & 0.14131 & 0.86891 \\
SKT does not Granger Cause RGDP & 0.76510 & 0.47587 \\
RGDP does not Granger Cause SKT & 0.48859 & 0.61923 \\
SMC does not Granger Cause RGDP & 2.09544 & 0.14410 \\
RGDP does not Granger Cause SMC & 0.72795 & 0.49285 \\
CPS does not Granger Cause RGDP & 0.46737 & 0.63201 \\
RGDP does not Granger Cause CPS & 1.29017 & 0.29292 \\
BM2 does not Granger Cause RGDP & 0.85931 & 0.43559 \\
RGDP does not Granger Cause BM2 & 1.63030 & 0.21601 \\
CPI does not Granger Cause RGDP & 1.99881 & 0.15657 \\
RGDP does not Granger Cause CPI & 0.39802 & 0.67583 \\
GDPV does not Granger Cause EXRV & 1.04683 & 0.36593 \\
EXRV does not Granger Cause GDPV & 0.02922 & 0.97124 \\
SKT does not Granger Cause EXRV & 0.06047 & 0.94146 \\
\hline
\end{tabular}




\begin{tabular}{lll}
\hline Null Hypothesis: & F-Statistic & Probability \\
\hline EXRV does not Granger Cause SKT & 3.16378 & 0.05959 \\
SMC does not Granger Cause EXRV & 0.03251 & 0.96805 \\
EXRV does not Granger Cause SMC & 5.10623 & 0.01382 \\
CPS does not Granger Cause EXRV & 0.98167 & 0.38867 \\
EXRV does not Granger Cause CPS & 2.22999 & 0.12848 \\
BM2 does not Granger Cause EXRV & 1.32311 & 0.28432 \\
EXRV does not Granger Cause BM2 & 2.71293 & 0.08585 \\
CPI does not Granger Cause EXRV & 0.18231 & 0.83444 \\
EXRV does not Granger Cause CPI & 2.29390 & 0.12171 \\
SKT does not Granger Cause GDPV & 0.00650 & 0.99352 \\
GDPV does not Granger Cause SKT & 0.47561 & 0.62701 \\
SMC does not Granger Cause GDPV & 0.04733 & 0.95386 \\
GDPV does not Granger Cause SMC & 0.89115 & 0.42282 \\
CPS does not Granger Cause GDPV & 0.08950 & 0.91468 \\
GDPV does not Granger Cause CPS & 0.65633 & 0.52746 \\
BM2 does not Granger Cause GDPV & 0.02364 & 0.97666 \\
GDPV does not Granger Cause BM2 & 0.41510 & 0.66474 \\
CPI does not Granger Cause GDPV & 0.03948 & 0.96135 \\
GDPV does not Granger Cause CPI & 0.81181 & 0.45542 \\
\hline
\end{tabular}

Source: - Author's computation (2016)

From the above table, there is no causality between financial deepening variables and economic growth. Also no causality between financial deepening and growth volatility but there is a unidirectional causality between exchange rate volatility (exrv), and stock traded (skt), stock market capitalization (smc) and broad money (BM2).

\subsection{Summary of Results}

Financial deepening refers to the increased provision of financial services with wider choice of financial services which will helps to dampen the volatility of the macroeconomic variables, improve macroeconomic policy effectiveness, and support inclusive growth.

The main questions raised in this paper are: does financial deepening dampens growth and exchange rate volatility and at same time support growth. Also, what is the pattern of causality between financial depth, macro-volatility and economic growth? The study outcome shows that there is a long-run relationship between financial deepening, exchange rate volatility and economic growth while the error correction term indicates that there is no long-run impact of financial depth on growth volatility. Also there is no short run impact of financial depth on exchange rate and growth volatility though most of the variables show signs of dampening the volatility of exchange rate and growth.

The short run impact of financial depth on economic growth designate that the stock traded (in lag $(1,2,3)$, credit to private sector in lag (1 and 3$)$, the broad money in lag (1 and 2) all have a significant impact on economic growth. However, Credit to Private at lag 1 and Broad Money 2 at lag (2) is used to reduce the growth level. Stock market capitalization has no significant impact on growth. The control variables; exchange rate volatility in lag (1 and 3) and consumer price index in lag (2) have negative and significant impact on the level of growth for the period under review. Finally, there is no causality between financial deepening variable and economic growth. Also no causality between financial deepening and growth volatility but there is a unidirectional causality between exchange rate volatility, stock traded, stock market capitalization, and broad money.

\subsection{Conclusion and Recommendation}

The objectives of this paper are in two-folds: an assessment of the short and long run impact of financial deepening on macroeconomic volatility and economic growth, secondly, to check the causal relationship among different components of financial depth, volatility and growth.

From our result, there is a long run impact of financial deepening on exchange rate volatility and economic growth while the error correction term indicates that there is no long run impact of financial depth on growth volatility. Also, there is no short run impact of financial depth on exchange rate and growth volatility though most of the variables show signs of dampening the volatility of exchange rate and growth. This is against the a priori expectation and did not support the results of existing works that affirmed that financial deepening is a vital instrument towards mitigation of volatility (see [38, 2, 49, 50, 51].

[11] found a supple leading hypothesis in Tanzania and Demand following hypothesis in Kenya and South Africa, [12] found a bi-causality relationship in Japan. Many authors have equally discovered a direct impact of financial sector development on economic growth; [13, 14, 15] among others. While $[16,17,18]$ established no significant impact of financial development on economic growth.

Based on the above result, there is need for government and policy makers to evolve measures that will deepen the financial sector and promote inclusive growth. This will help in reducing the financial risks and volatility, and in turn propel economic growth. Secondly, the causal result indicates that there is no causality between financial depth and volatility (exchange rate and growth volatility). Therefore, fluctuations in the economic indicators may have been induced by some structural imbalance relating to religious and political upheavals in the economy. There is need for government to develop strategies to address underlying challenges that hinder foreign investment in the financial sector.

\section{Appendix}

Error Correction Result for Model 1

D(EXRV) C d(RGDP(-1)) d(RGDP(-2)) d(RGDP(-3)) D(SKT(-1)) D(SKT(-2)) D(SKT(-3)) D(SMC(-1)) D(SMC(2)) $\quad \mathrm{D}(\mathrm{SMC}(-3)) \quad \mathrm{D}(\mathrm{CPS}(-1)) \quad \mathrm{D}(\mathrm{CPS}(-2)) \quad \mathrm{D}(\mathrm{CPS}(-3))$ D(BM2(-1)) D(BM2(-2)) D(BM2(-3)) D(CPI(-1)) D(CPI(-2)) $\mathrm{D}(\mathrm{CPI}(-3))+\mathrm{U}(-1)$ 
Table A1. Error Correction Model I.

\begin{tabular}{|c|c|c|c|c|}
\hline Dependent Variable: D(EXRV) & & & & \\
\hline \multicolumn{5}{|l|}{ Method: Least Squares } \\
\hline \multicolumn{5}{|l|}{ Date: 08/17/15 Time: $12: 26$} \\
\hline \multicolumn{5}{|l|}{ Sample (adjusted): 19852012} \\
\hline \multicolumn{5}{|c|}{ Included observations: 28 after adjustments } \\
\hline Variable & Coefficient & Std. Error & t-Statistic & Prob. \\
\hline $\mathrm{C}$ & 5.871959 & 8.877876 & 0.661415 & 0.5155 \\
\hline $\mathrm{D}(\mathrm{SKT}(-2))$ & 18.99341 & 14.56656 & 1.303906 & 0.2064 \\
\hline $\mathrm{D}(\mathrm{SKT}(-3))$ & 8.603156 & 5.466588 & 1.573771 & 0.1305 \\
\hline $\mathrm{D}(\mathrm{SMC}(-3))$ & -3.073568 & 3.283933 & -0.935941 & 0.3599 \\
\hline $\mathrm{D}(\mathrm{CPS}(-2))$ & -4.645098 & 3.214775 & -1.444922 & 0.1632 \\
\hline $\mathrm{D}(\mathrm{CPI}(-1))$ & 1.082445 & 1.234189 & 0.877049 & 0.3904 \\
\hline $\mathrm{U}(-1)$ & -0.452218 & 0.214043 & -2.112742 & 0.0468 \\
\hline R-squared & 0.212936 & Mean dependent var & & 9.569643 \\
\hline Adjusted R-squared & -0.011940 & S.D. dependent var & & 30.07563 \\
\hline S.E. of regression & 30.25465 & Akaike info criterion & & 9.869495 \\
\hline Sum squared resid & 19222.22 & Schwarz criterion & & 10.20255 \\
\hline Log likelihood & -131.1729 & F-statistic & & 0.946904 \\
\hline Durbin-Watson stat & 2.025133 & Prob (F-statistic) & & 0.483419 \\
\hline \multicolumn{5}{|c|}{ Breusch-Godfrey Serial Correlation LM Test for model 1: } \\
\hline F-statistic & 0.349077 & Probability & & 0.711306 \\
\hline Obs*R-squared & 1.329985 & Probability & & 0.514277 \\
\hline \multicolumn{5}{|l|}{ ARCH Test for model 1: } \\
\hline F-statistic & 0.021772 & Probability & & 0.978483 \\
\hline Obs*R-squared & 0.049131 & Probability & & 0.975734 \\
\hline Normality Test for model 1 & & & & \\
\hline
\end{tabular}

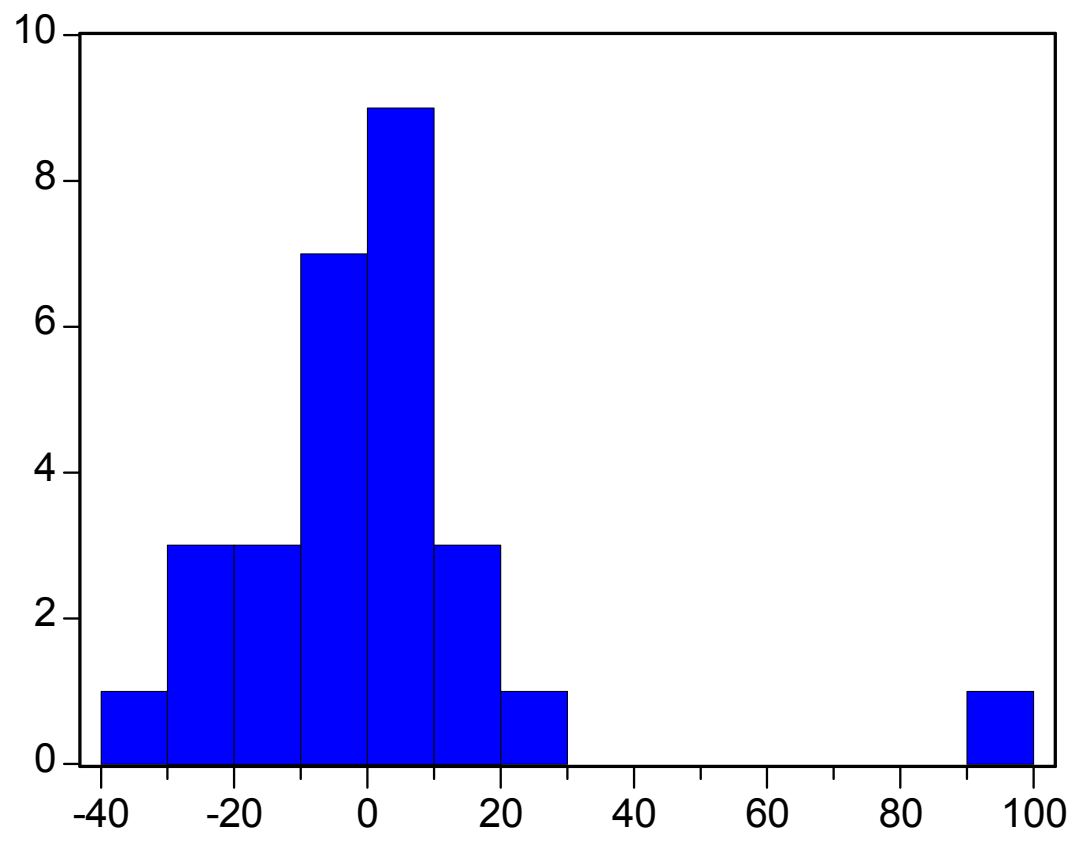

\section{Series: Residuals \\ Sample 19852012 \\ Observations 28}

Mean

Median

$-1.68 \mathrm{e}-15$

Maximum

$-0.185257$

Minimum

98.73944

Std. Dev.

$-33.84799$

Skewness

23.68907

Kurtosis

2.521935

11.98408

Jarque-Bera

123.8467

Probability 
Table A2. Error Correction Result Model 2.

\begin{tabular}{|c|c|c|c|c|}
\hline \multicolumn{5}{|c|}{ Dependent Variable: D(GDPV) } \\
\hline \multicolumn{5}{|c|}{ Method: Least Squares } \\
\hline \multicolumn{5}{|c|}{ Date: 08/16/15 Time: 22:50 } \\
\hline \multicolumn{5}{|c|}{ Sample (adjusted): 19852012} \\
\hline \multicolumn{5}{|c|}{ Included observations: 28 after adjustments } \\
\hline Variable & Coefficient & Std. Error & t-Statistic & Prob. \\
\hline $\mathrm{C}$ & -1.779322 & 0.751269 & -2.368423 & 0.0286 \\
\hline $\mathrm{D}(\operatorname{EXRV}(-1))$ & 0.018182 & 0.020368 & 0.892714 & 0.3832 \\
\hline D(SKT(-1)) & -0.281107 & 0.305650 & -0.919703 & 0.3693 \\
\hline $\mathrm{D}(\mathrm{CPS}(-1))$ & 0.299787 & 0.328964 & 0.911305 & 0.3736 \\
\hline $\mathrm{D}(\mathrm{CPS}(-3))$ & -0.653300 & 0.410213 & -1.592587 & 0.1278 \\
\hline $\mathrm{D}(\mathrm{BM} 2(-1))$ & -0.410274 & 0.356118 & -1.152074 & 0.2636 \\
\hline $\mathrm{D}(\mathrm{BM} 2(-3))$ & 0.511035 & 0.370071 & 1.380912 & 0.1833 \\
\hline $\mathrm{D}(\mathrm{CPI}(-3))$ & 0.245263 & 0.121807 & 2.013532 & 0.0584 \\
\hline $\mathrm{U}(-1)$ & -0.019389 & 0.021659 & -0.895227 & 0.3819 \\
\hline R-squared & 0.242101 & \multicolumn{2}{|l|}{ Mean dependent var } & -0.643214 \\
\hline Adjusted R-squared & -0.077014 & \multicolumn{2}{|l|}{ S.D. dependent var } & 2.437224 \\
\hline S.E. of regression & 2.529334 & \multicolumn{2}{|l|}{ Akaike info criterion } & 4.948881 \\
\hline Sum squared resid & 121.5531 & \multicolumn{2}{|l|}{ Schwarz criterion } & 5.377089 \\
\hline Log likelihood & -60.28433 & \multicolumn{2}{|l|}{ F-statistic } & 0.758663 \\
\hline Durbin-Watson stat & 1.325730 & \multicolumn{2}{|l|}{ Prob (F-statistic) } & 0.641895 \\
\hline \multicolumn{5}{|c|}{ Breusch-Godfrey Serial Correlation LM Test for model 2: } \\
\hline F-statistic & 0.022229 & \multicolumn{2}{|l|}{ Probability } & 0.978097 \\
\hline Obs*R-squared & 0.205943 & \multicolumn{2}{|l|}{ Probability } & 0.902153 \\
\hline \multicolumn{5}{|c|}{ ARCH Test for model 2: } \\
\hline F-statistic & 0.171587 & \multicolumn{2}{|l|}{ Probability } & 0.843395 \\
\hline Obs*R-squared & 0.382233 & \multicolumn{2}{|l|}{ Probability } & 0.826036 \\
\hline
\end{tabular}

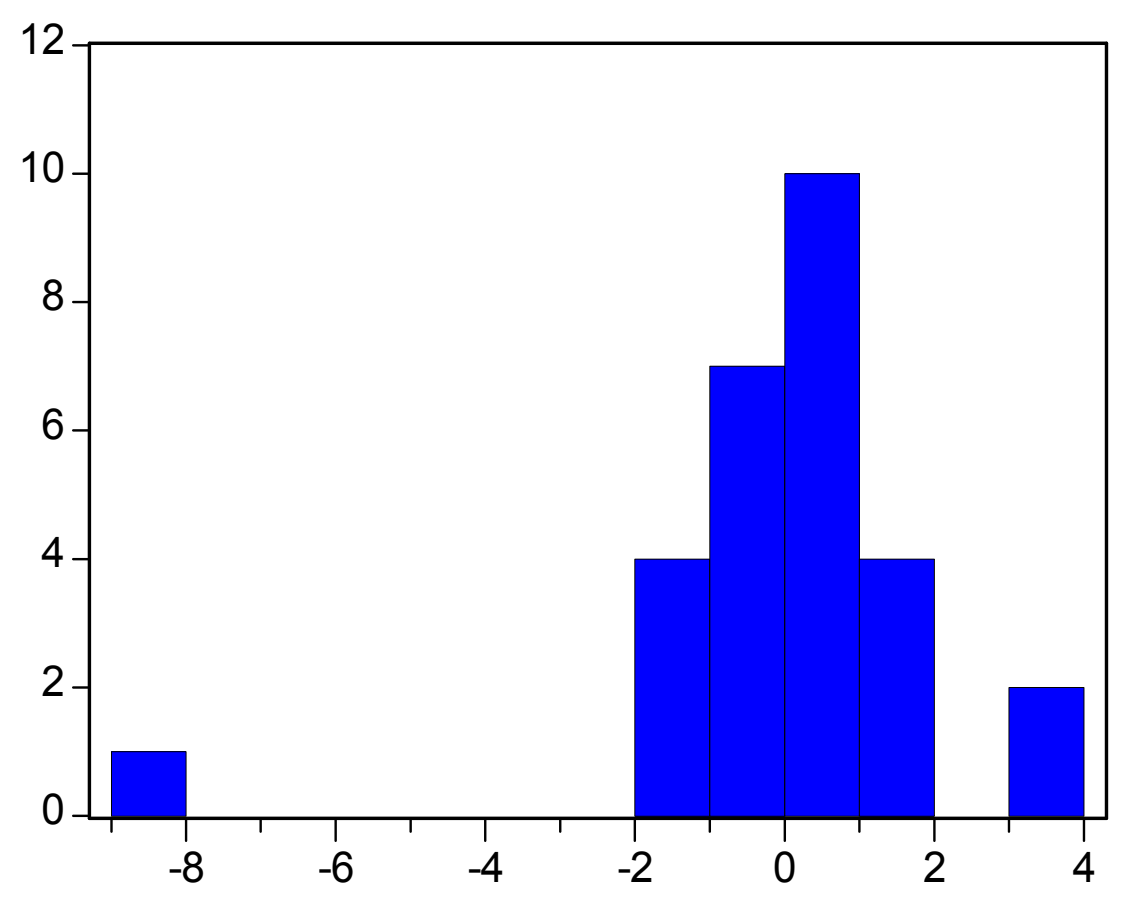

\section{Series: Residuals \\ Sample 19852012 \\ Observations 28}

Mean

$-1.79 \mathrm{e}-16$

Median

0.057424

Maximum

3.161387

Minimum

$-8.175049$

Std. Dev.

1.959285

Skewness

$-2.423187$

Kurtosis

12.20712

Jarque-Bera

126.3014

Probability

0.000000

Figure A2. Normality Test for model 2. 
Table A3. Error Correction Result Model 3.

\begin{tabular}{|c|c|c|c|c|}
\hline Dependent Variable: D(RGDP) & & & & \\
\hline \multicolumn{5}{|l|}{ Method: Least Squares } \\
\hline \multicolumn{5}{|l|}{ Date: 08/17/15 Time: 22:12 } \\
\hline \multicolumn{5}{|l|}{ Sample (adjusted): 19852012} \\
\hline \multicolumn{5}{|c|}{ Included observations: 28 after adjustments } \\
\hline Variable & Coefficient & Std. Error & t-Statistic & Prob. \\
\hline $\mathrm{C}$ & 4.399410 & 1.270167 & 3.463646 & 0.0032 \\
\hline $\mathrm{D}(\operatorname{EXRV}(-1))$ & -0.134912 & 0.035413 & -3.809632 & 0.0015 \\
\hline $\mathrm{D}(\operatorname{EXRV}(-3))$ & -0.091580 & 0.028811 & -3.178659 & 0.0058 \\
\hline $\mathrm{D}(\mathrm{SKT}(-1))$ & 2.164419 & 0.647155 & 3.344515 & 0.0041 \\
\hline $\mathrm{D}(\mathrm{SKT}(-2))$ & 2.685199 & 0.775681 & 3.461731 & 0.0032 \\
\hline $\mathrm{D}(\mathrm{SKT}(-3))$ & 1.111468 & 0.558041 & 1.991731 & 0.0638 \\
\hline $\mathrm{D}(\mathrm{CPS}(-1))$ & -2.725916 & 0.611765 & -4.455826 & 0.0004 \\
\hline $\mathrm{D}(\mathrm{CPS}(-3))$ & 2.200032 & 0.413663 & 5.318420 & 0.0001 \\
\hline D(BM2(-1)) & 2.615627 & 0.562592 & 4.649241 & 0.0003 \\
\hline D(BM2(-2)) & -1.416184 & 0.365820 & -3.871262 & 0.0014 \\
\hline $\mathrm{D}(\mathrm{CPI}(-2))$ & -0.535865 & 0.167112 & -3.206628 & 0.0055 \\
\hline $\mathrm{U}(-1)$ & 0.151106 & 0.039831 & 3.793700 & 0.0016 \\
\hline R-squared & 0.714608 & Mean dependent var & & 0.414286 \\
\hline Adjusted R-squared & 0.518400 & S.D. dependent var & & 5.278922 \\
\hline S.E. of regression & 3.663434 & Akaike info criterion & & 5.732206 \\
\hline Sum squared resid & 214.7319 & Schwarz criterion & & 6.303151 \\
\hline Log likelihood & -68.25088 & F-statistic & & 3.642106 \\
\hline Durbin-Watson stat & 1.905952 & Prob (F-statistic) & & 0.009674 \\
\hline \multicolumn{5}{|c|}{ Breusch-Godfrey Serial Correlation LM Test for model 3: } \\
\hline F-statistic & 0.072828 & Probability & & 0.930303 \\
\hline Obs*R-squared & 0.445935 & Probability & & 0.800141 \\
\hline \multicolumn{5}{|l|}{ ARCH Test for model 3: } \\
\hline F-statistic & 0.081035 & Probability & & 0.778244 \\
\hline Obs*R-squared & 0.087235 & Probability & & 0.767722 \\
\hline
\end{tabular}

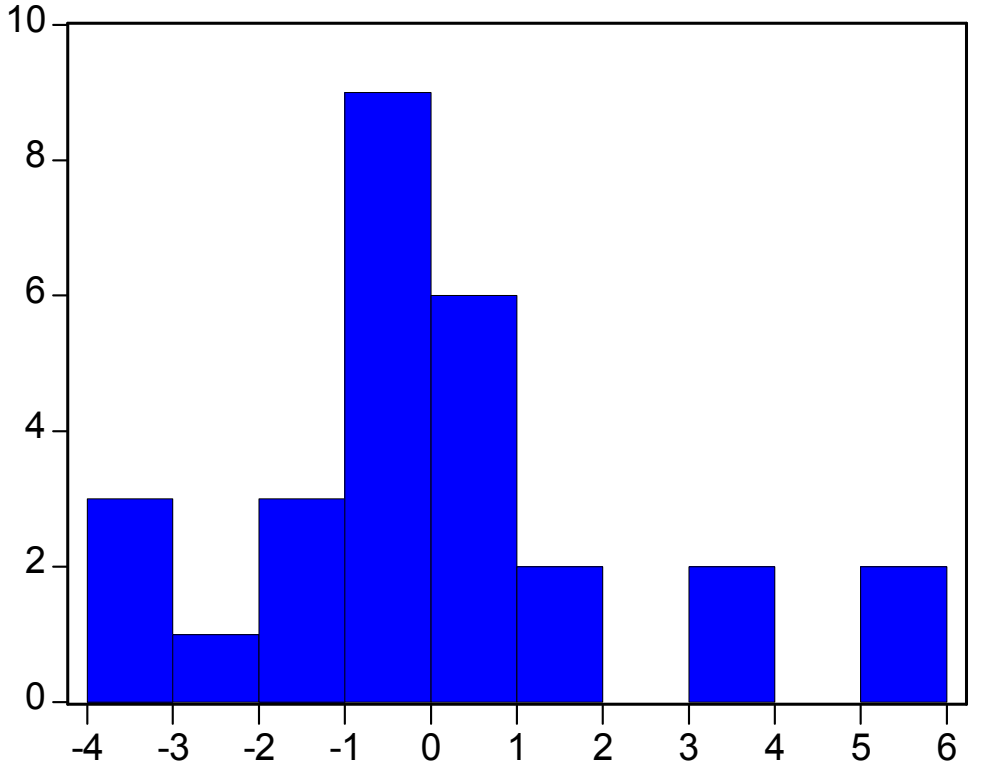

Figure A3. Normality Test for model 3.

$\begin{array}{ll}\text { Series: Residuals } \\ \text { Sample 1985 } 2012 \\ \text { Observations } 28 \\ \text { Mean } & -1.37 e-15 \\ \text { Median } & -0.206065 \\ \text { Maximum } & 5.981072 \\ \text { Minimum } & -3.850695 \\ \text { Std. Dev. } & 2.382356 \\ \text { Skewness } & 0.735939 \\ \text { Kurtosis } & 3.718631 \\ & \\ \text { Jarque-Bera } & 3.129996 \\ \text { Probability } & 0.209088\end{array}$


Anuli Regina Ogbuagu and Dennis Brown Ewubare: Financial Deepening Implications for Macro-economic Volatility and Economic Growth in Nigeria, A Multivariate Approach

Table A4. Pairwise Granger Causality Tests for objective 2.

\begin{tabular}{|c|c|c|c|}
\hline \multicolumn{4}{|l|}{ Pairwise Granger Causality Tests for objective 2} \\
\hline \multicolumn{4}{|l|}{ Date: 08/16/15 Time: $23: 22$} \\
\hline \multicolumn{4}{|l|}{ Sample: 19812012} \\
\hline \multicolumn{4}{|l|}{ Lags: 2} \\
\hline Null Hypothesis: & Obs & F-Statistic & Probability \\
\hline EXRV does not Granger Cause RGDP & 30 & 3.08253 & 0.06359 \\
\hline RGDP does not Granger Cause EXRV & & 0.57216 & 0.57152 \\
\hline GDPV does not Granger Cause RGDP & 30 & 1.35724 & 0.27569 \\
\hline RGDP does not Granger Cause GDPV & & 0.14131 & 0.86891 \\
\hline SKT does not Granger Cause RGDP & 30 & 0.76510 & 0.47587 \\
\hline RGDP does not Granger Cause SKT & & 0.48859 & 0.61923 \\
\hline SMC does not Granger Cause RGDP & 30 & 2.09544 & 0.14410 \\
\hline RGDP does not Granger Cause SMC & & 0.72795 & 0.49285 \\
\hline CPS does not Granger Cause RGDP & 30 & 0.46737 & 0.63201 \\
\hline RGDP does not Granger Cause CPS & & 1.29017 & 0.29292 \\
\hline BM2 does not Granger Cause RGDP & 30 & 0.85931 & 0.43559 \\
\hline RGDP does not Granger Cause BM2 & & 1.63030 & 0.21601 \\
\hline CPI does not Granger Cause RGDP & 30 & 1.99881 & 0.15657 \\
\hline RGDP does not Granger Cause CPI & & 0.39802 & 0.67583 \\
\hline GDPV does not Granger Cause EXRV & 30 & 1.04683 & 0.36593 \\
\hline EXRV does not Granger Cause GDPV & & 0.02922 & 0.97124 \\
\hline SKT does not Granger Cause EXRV & 30 & 0.06047 & 0.94146 \\
\hline EXRV does not Granger Cause SKT & & 3.16378 & 0.05959 \\
\hline SMC does not Granger Cause EXRV & 30 & 0.03251 & 0.96805 \\
\hline EXRV does not Granger Cause SMC & & 5.10623 & 0.01382 \\
\hline CPS does not Granger Cause EXRV & 30 & 0.98167 & 0.38867 \\
\hline EXRV does not Granger Cause CPS & & 2.22999 & 0.12848 \\
\hline BM2 does not Granger Cause EXRV & 30 & 1.32311 & 0.28432 \\
\hline EXRV does not Granger Cause BM2 & & 2.71293 & 0.08585 \\
\hline CPI does not Granger Cause EXRV & 30 & 0.18231 & 0.83444 \\
\hline EXRV does not Granger Cause CPI & & 2.29390 & 0.12171 \\
\hline SKT does not Granger Cause GDPV & 30 & 0.00650 & 0.99352 \\
\hline GDPV does not Granger Cause SKT & & 0.47561 & 0.62701 \\
\hline SMC does not Granger Cause GDPV & 30 & 0.04733 & 0.95386 \\
\hline GDPV does not Granger Cause SMC & & 0.89115 & 0.42282 \\
\hline CPS does not Granger Cause GDPV & 30 & 0.08950 & 0.91468 \\
\hline GDPV does not Granger Cause CPS & & 0.65633 & 0.52746 \\
\hline BM2 does not Granger Cause GDPV & 30 & 0.02364 & 0.97666 \\
\hline GDPV does not Granger Cause BM2 & & 0.41510 & 0.66474 \\
\hline CPI does not Granger Cause GDPV & 30 & 0.03948 & 0.96135 \\
\hline GDPV does not Granger Cause CPI & & 0.81181 & 0.45542 \\
\hline
\end{tabular}

\section{References}

[1] A. R. Ogbuagu and D. B. Ewubare (2014). Financial Deepening and Inflation in Nigeria, "An Open Economy Model Approach." Journal of Economic and Sustainable Development; 5 (25): ISSN 2222- 2855 (online)

[2] P. Aghion, G. Angeletos,. A Banerjee, and K. Manova, (2010), "Volatility and Growth: Credit Constraints and the Composition Of Investment," Journal of Monetary Economics; 57, Pp 246-65. Available; http://web.stanford.edu/ manova/AABM.pdf

[3] International Monetary Fund (2012). Enhancing Financial Sector Surveillance in Low - Income Countries- Financial Deepening and Macro- Stability; Board Paper.

[4] H. Patrick (1966) 'Financial Development and Economic Growth in Underdeveloped countries', EconomicDevelopment and Cultural Change, 14 (1), Pp 174-189.

[5] P. Aghion, P. Bacchetta, Romain Rancere, and Kenneth Rogoff (2009). "Exchange Rate Volatility and Productivity Growth. The Role of Financial Development". Journal of Monetary Economics; 56, Pp 497-513. 
[6] R. I. McKinnon, (1973) "Money and capital in economic development", the Brookings institution, Washington D. C.

[7] E. S. Shaw, (1973). "Financial deepening in economic development, New York, Oxford University Press, London and New York. Available; http://www.rbi.org.in/script/Bsspeechesview.aspx?id=310

[8] C. Calderon, and L Liu, (2002) "The direction of causality between financial development and economic growth", working paper No. 184. Available; https://ideas.repec.org/p/chb/bcchwp/184.html

[9] R. Levine, N. Loayza and T. Beck (2002) "Financial intermediation and growth: causality and causes" Journal of Monetary Economic, 46, Pp 31-77.

[10] H. Marashdeh and H. Al-Malkawi. (2014). "Financial Deepening and Economic Growth in Saudi Arabia" Journal of Emerging Market Finance 13 (2); Pp 139 - 154. doi: $10.1177 / 0972652714541339$

[11] N. Odhiambo (2007). "Supply - Leading Versus Demand Following Hypothesis; Empirical Evidence from Three SSA Countries. African Development Review 19 (2); Pp252-280. DOI: $10.1111 / \mathrm{j} .1467-8268.2007 .00161 . \mathrm{x}$

[12] Chang Shu-Chen and Wu Chan - Hsian (2012). "The Relationship between Financial Deepening and Economic Growth in Taiwan" Journal of Business, Economics, Financial Science and Management; 143: Pp 205 - 210. Dio: 10./007/978-3-642-27966-9.29

[13] J. U. Onwumere. And G. Ibeh. (2013), "Financial Strucutre on Economic Growth; Evidence from Nigeria" Global Journal of Management and Business Research Finance; 13 (5): ISSN; 2249-4588.

[14] S. Ayodele (2012). "Financial Intermediation and Economic Growth in Nigeria", British Journal of Arts and Social Science; 4 (2), ISSN- 2046-9578.

[15] J. Ang (2007), "Financial Deepening and Economic Development in Malaysia" Asian Business and Economics Research Unit, Discussion Paper 42, Available; https://ideas.repec.org/a/eee/moneco/v56y2009i4p494513.html

[16] C. Denizer, M. Iyigun, and A. Owen, (2002), "Finance and Macroeconomic Volatility," Contribution to Macroeconomics; 2. Available; http://mpra.ub.uni-muenchen.de/11113

[17] Acemoglu, Daron, Simon Johnson, and James A. Robinson. (2003). "An African Success: Botswana." In Dani Rodrik, ed., In Search of Prosperity: Analytic Narratives on Economic Growth. Princeton: Princeton University Press.

[18] Beck, T., M. Lundberg, and G. Majnoni, 2006, "Financial Intermediary Development and Growth Volatility: Do Intermediaries Dampen or Magnify Shocks," Journal of International Money andFinance; 25: Pp11461167.https://pure.uvt.nl/portal/files/1024310/blm.pdf

[19] S. Odeniran and E. Udeaja (2010). "Financial Development and Economic Growth" Empirical Evidence from Nigeria. Central Bank of Nigeria Economic and Financial Review; 20: 91-124 Available -www.cenbank.org/out/2012

[20] C. Osuji and E. Chigbu (2012). "An Evaluation of Financial Development and Economic Growth of Nigeria "A Causality Test" Kuwait Chapter of Arabian Journal of Business and
Management Review 1 (10): Pp 27-44.

[21] Balago Garba (2014). "Financial Sector Development and Economic Growth in Nigeria, "An Empirical Investigation". International Journal of Finance and Accounting; 3 (4): Pp253-265. doi: 5923/j.ijfa.20140304.05

[22] International Monetary Fund (2015). "Rethinking Financial Deepening: Stability and Growth in Emerging Markets" IMF Staff Discussion Note Pp. 1-41

[23] D. Acemoglu, and F. Zilibotti, (1997) "Was Prometheus Unbound by Chance? Risk, Diversification, and Growth", Journal of Political Economy, Vol. 105, No 4, 1997, pp. 709-51.

[24] Moore, B. J (1986), "Inflation and Financial Deepening" Journal of Development Economics, January/February; Pp 125-133.

[25] R. Levine, (2005), "Finance and Growth: Theory and Evidence" in P. Aghion and S. N. Durlauf (eds.), Handbook of Economic Growth, Vol. 1A, North-Holland, Amsterdam, 865-934.

[26] Beck Thomas (2011), "The Role of Finance in Economic Development; Benefits, Risks and Politics. European Banking Centre Discussion Paper No 211-038, Avalaible; http://www.unitus.it/dipartimenti/distateq/garofalo/SSRNid1974471.pdf

[27] International Monetary Fund (2013). "Nigeria Financial Sector Stability Assessment" IMF Country Reput No 13/140. Available:

https://www.imf.org/external/pubs/ft/scr/2013/cr.13140.pdf

[28] N. Nader, (2005). "Deregulation, Financial Deepening and Economic Growth; the Case of Latin America" The Quarterly Review of Economics and Finance: 45 (2-3); pp 447-459.

[29] M. Hazem and A. Husam (2014). "Financial Deepening and Economic Growth in Saudi Arabia". Journal of emerging Market Finance: 13 (2); pp 139-154. Available; sagepub.com/content/13/2/139.short

[30] M. Bakang (2015). "Effect of Financial Deepening on Economic Growth in Kenya" International Journal of Business and Commerce: 4 (7); pp 1-50.

[31] A. Darrat (2006). "Are Fiancial Deepening and Economic Growth Causally Related? Another look at the Evidence" International Economic Journal; 13 (3): pp 13-32. http://dx.doi.org//0/1080/101687399

[32] Adjei S. Bismar Kosee and Mensah O (2016). Financial Deepening and Economic Growth in Ghana; A Cointegration Analysis. International Journal of Current Research: 8 (1); pp 25736-25743.

[33] V. Murinde and S. Fern (2010). “Financial Development and Economic Growth in Singapore: Demand-Following or Supply Leading?" Applied Financial Economics; 4 (6): Pp 391-404.

[34] Tsangyao Chang (2010). Financial Development and Econoomic Growth in Mainland China. A note on testing Demand Following or Supply Leading Hypothesis" Journal of Applied Economics Letter; 9 (13): pp 869-873.

[35] M. Habibullah and Yoke-Kee (2007). "Does Financial Developemnt cause Economic Growth? Apanel Data Dynamic Analysis for Asian Developing Countries" Journal of Asian Pacific Economy: 11 (4); pp 377-393. 
[36] J. Thornton, (1994). "Financial Deepening and Economic Growth: Evidence from Asian Economics". International Monetary Fund/ University of Wales; Bangor in JSTOR 18 (1); Pp 41-51. Available: http//www.jstor.org/stable/25830365

[37] P. Ardic and H. Damar (2006). "Financial Sector Deepening and Economic Growth: Evidence from Turkey. Pp. 1-25. Available; www.

Luc.edu/orgs/meea/volume9/pdfs/dammar\%20Ardic\%20\%20 paper.pdf

[38] A. Kose, S. Eswar and Macro Terrones (2003) "Financial Integration and Macroeconomic Volatility. IMF Working Paper WP/03/50. Pp 1-23.

[39] K. Andrew and M. Spiiegel (2007). "International Financial Remoteness and Macroeconomic Volatility" International Monetary Fund, pp 1-41.

[40] Era Dable- Norris \& Srivisal Narapong (2013). "Revisiting the Link between Finance and Macroeconomic Volatility. IMF Working Paper. WP/13/29. Pp 1-33. Available: http://www./IMF.org.external/pubs/ft/wp/2013/wp1329pdf

[41] Jinyoung Awang and Jong Ha Lee (2013). Financial Deepening and Business Cycle Volatility in Korea. Journal of Applied Financial Economics Volumes 23; 21. Taylor \& Francis online.

[42] H. Marashdeh, Husam-Aldin, and N. Al-Malkawi (2014). "Financial Deepening and Economic Growth in Saudi Arabia", Journal of Emerging Market Fiance 13 (2); Pp 139154. doi: $10.1177 / 0972652714541339$

[43] Rahman Matiur and Mustafa Muhamadu (2015). Financial Deepening and Stock Market Returns; Panel Cointegration Analyses. Available; http://swfa2015.uno.edu/D_International_Markets_II/paper_2 32.pdf

[44] A. Ahmed and S. Surdi. (2009). "Do Financial and Trade Liberalization cause Macroeconomic Volatility in SubSaharan Africa?" Working Paper No 44, Centre for Strategic Economic Studies (CSES) Victoria University Melbourne. Pp $1-35$.
[45] V. Oriavwote. And S. Esheneke (2014). “An Empirical Assessment of Financial Sector Development and Economic Growth in Nigeria". International Review of Management and Business Research; 3 (1)

[46] A. Shittu, (2012). "Financial Intermediation and Economic Growth in Nigeria". British Journal of Art and Social Science, $2(2)$.

[47] M. Okoli (2013). "Evaluating The Nexus Between Financial Deepening and Stock Market in Nigeria", European Scientific Journal: 8/15; ISSN- 1857-7431.

[48] World Bank (2000). "Nigerian Financial Sector Review and Macroeconomic Environment. Document of World Bank. Avaible; http:openknowledge.worldbank.org

[49] A. Ogbuagu and E. Ifionu. (2015). "Causality between Capital Flow, Human Capital Development and Economic Growth; A Case of Nigeria". International Journal of Financial Research; 6 (3); pp 116-134.

[50] C. Raddatz, (2006), "Liquidity Needs and Vulnerability to Financial Underdevelopment," Journal of Financial Economics; 80: Pp 677-722.

[51] B. Larrain, (2006), "Do Banks Affect the Level and Composition of Industrial Volatility," Journal of Finance: 61: Pp 1897-1925.

[52] Era Dable- Norris \& Srivisal Narapong (2012). "Financial Depth and Macroeconomic Volatility; In Enhancing Financial Sector Surveillance in Low -Income Countries - Background Paper: Integrational Monetary Fund Paper. Available://www.imf.org/external/np/pp/eng/2012/041612a.pd $\mathrm{f}$

[53] J. U. Onwumere, F. Ozo, and O. Mounanu (2012). "The Impact of Financial Deepending on Economic Growth, Evidence from Nigeria." Research Journal of Finance and Accounting: 3 (10): ISSN 2222- 2897. 